\title{
Author: Kerem Öge
}

Abstract: In the last decade, the Extractive Industries Transparency Initiative (EITI) has grown in both popularity and influence. The ascendance of EITI is surprising because traditionally, leaders of resource-rich states prefer to tightly control their extractive industries. This paper investigates the underlying causes of EITI membership in order to understand its acceptance, even among some of the most authoritarian regimes. The paper argues that leaders of resource-rich countries use the EITI to consolidate their international prestige as eager reformers, which serves to both maintain and lure foreign investment. The cross-national and interrupted time series analyses reveal that EITI members not only have higher FDI levels compared to non-members, but these investments increase once countries join the initiative.

Keywords: Transparency, Extractive Industries, Foreign Direct Investment, Compliance, Globalization 
Author: Kerem Öge

\section{To Disclose or not to Disclose: How Global Competition for Foreign Direct Investment Influences Transparency Reforms in Extractive Industries}

\section{Introduction}

Since Tony Blair launched the Extractive Industries Transparency Initiative (EITI) in 2003, 51 resource-rich countries have become members to this public-private partnership, which seeks to promote revenue transparency in the extractive industries. The EITI membership now includes important producers of hydrocarbons and minerals such as Iraq, Kazakhstan, and Nigeria. As EITI members, these countries voluntarily disclose their financial transactions with foreign companies in the extractive industries. The growing popularity of the EITI is remarkable and puzzling at the same time. Traditionally, leaders of resource-rich states tightly control their extractive sector due to its strategic importance for the economy. Methods of 'control' may involve stealthy contracts, preferential treatments, and off-the-books financial transactions, which are naturally kept hidden from the public eye. Yet an increasing number of resource-rich states also endorse the EITI process of disclosing revenues from the sale of hydrocarbons and minerals despite the potential political costs of transparency.

To understand the reasons of EITI's popularity, even among some of the most authoritarian regimes, this paper problematizes the underlying causes of EITI membership. So far, the literature on resource governance does not offer a systematic analysis of why governments would voluntarily disclose revenues from extractive industries. Contributing to the literatures on transparency and policy diffusion, the analysis in this paper shows that the decision to join the EITI is partly motivated by 
Author: Kerem Öge

global competition for foreign direct investment. Specifically, based on series of logistic regressions, the research reveals that states that depend on foreign direct investment (FDI) for economic growth are more likely to be affiliated with the initiative. In addition, an interrupted time-series analysis shows that EITI-implementing countries experience higher levels of incoming FDI immediately following their membership. The results confirm that leaders of resource-rich countries use the EITI to consolidate their international prestige as eager reformers, which serves to maintain and/or lure foreign investment. Compliance with the EITI standard is an effective signal for countries to demonstrate their willingness to embrace open markets, which also explains the growing popularity of the initiative.

The paper is organized as follows: the first section focuses on the emergence of the norm of transparency in extractive industries and the EITI process. The next section analyses the reasons why countries might join the EITI, focusing particularly on material processes identified by the policy diffusion literature. The following sections present the model and the statistical analysis. The last section discusses the implications of the results for transparency promotion in resource-rich countries.

\section{Promoting Transparency in Extractive Industries}

Revenue Transparency became a global norm in extractive industries thanks to the efforts of various advocacy networks, including Revenue Watch (RW) and Publish What You Pay (PWYP), who made constant efforts to highlight transparency as a remedy for corruption and mismanagement in the resource sector. In the early 2000 s, these groups began to lobby international oil companies to disclose their receipts from host countries. 
Author: Kerem Öge

In response to these demands, British Petroleum (BP) published a bonus payment of $\$ 111$ million to the Angolan government for an offshore license in 2001. The subsequent the backlash from the Angolan government at the time highlighted the collective action problem faced by multinational companies and eventually inspired the creation of the EITI in $2003 .^{1}$

What does transparency imply for resource-rich countries? In the extractive industries, transparency broadly refers to public availability of information on how resources are managed, and applies particularly to public revenues, expenditures, awarding of contracts and licenses, public procurement, politician's personal wealth, appointments and promotions, clarity of roles and responsibilities, and open budget processes (IMF, 2007; Kolstad \& Wiig, 2009, p. 526).

In theory, transparency has substantial political costs (Berliner, 2014) because it can make corruption riskier for those in power by allowing the public to monitor resource management and by initiating a fair selection process for the resource bureaucracy. Yet, leaders might tolerate certain transparency reforms when there is strong political competition (Hollyer, Rosendorff, \& Vreeland, 2011) or a possibility of government turnover (Berliner, 2014). In certain cases, even authoritarian governments can favor transparency to improve local governance and efficiency (Lorentzen, 2014). However in resource-rich countries the existence of easy access to rents removes the necessity of such gestures. Leaders of these countries often prefer a secretive business environment that permits unfair access to rents and undermines incentives for institutional reform. As a result, the majority of resource-rich countries currently have non-transparent commercial

\footnotetext{
${ }^{1}$ Interview with Dr. Francisco Paris, EITI Regional Director, 10 May 2011, Oslo.
} 
Author: Kerem Öge

relations and suffer from high levels of corruption (Revenue Watch, 2013; World Bank, 2013).

In this context, it is not surprising that transparency advocates in resource-rich countries presume a possible causal relationship between transparency and corruption. However, this relationship is yet to be empirically demonstrated and studies on transparency's impact on corruption reveal conflicting results. On one hand, various works highlight the positive aspects of transparency. For example Islam (2006) shows that countries with better informational flows also have higher governance levels. Similarly, when transparency is measured by the freedom of information, a negative correlation exists between corruption and transparency (Brunetti \& Weder, 2003).

On the other hand, partial implementation of transparency may undermine its alleged positive impact on good governance. For example, making only revenues transparent might not address corruption in resource-rich countries, where off-the-books payments to government officials are not likely to be reported (Kolstad \& Wiig, 2009, p. 525; Öge, 2014, 2016). Similarly, Fox (2007) distinguishes between clear and opaque transparency where the latter conceals the actual mechanisms of the decision-making process and reveals only to the extent demanded by international institutions. This opaque form of transparency, such as disclosing only aggregate data on resource revenues as opposed to individual receipts from each company, is not likely to have a moderating impact on corruption.

While the actual impact of transparency on good governance is open to debate, currently the norm is more popular than ever (EITI, 2014b). Yet, many developing countries lack the necessary mechanisms and/or incentives to ensure that the resource 
Author: Kerem Öge

management process is transparent. In such contexts, external influences can play a significant role in transparency promotion. Firstly, international financial institutions (IFIs) increasingly use technical assistance to help key actors internalize the norm of transparency. For example, the World Bank helps local civil society groups to improve their monitoring skills. Similarly, the IMF published its "Guide on Resource Revenue Transparency" in 2007, which provides references of good and best practices of resource revenue transparency, as a guideline for both governments and civil society groups (IMF, 2007, p. vii). Secondly, transnational advocacy networks (TANs), such as PWYP, RW, and Transparency International (TI), help establish domestic civil society coalitions to push for more transparency in the management of resource revenues. Building up on the success of these networks, the EITI has been the most influential organization to promote revenue transparency in the last decade.

\section{The Extractive Industries Transparency Initiative}

The EITI is a coalition of countries, companies, and civil society groups that aims to establish global standards of transparency in extractive industries. The membership of the EITI increased consistently since it was launched in 2003, following the international support it received from the United Kingdom and the World Bank. As of April 2016, 51 resource-rich countries implement the EITI standard (EITI, 2013b).

The wide popularity of the EITI among resource-rich countries is partially due to its status as a public-private entity. The stakeholders of the EITI include affluent governments such as the United Kingdom, Germany, Qatar, the United States, which provide political, technical, and financial support to the initiative, but are not necessarily 
Author: Kerem Öge

EITI-implementing countries; global advocacy networks; and international companies including BP, Chevron, and ExxonMobil. Companies, in particular, are key actors in the EITI process. Currently more than 90 largest oil gas and mining companies officially support the EITI process. In certain cases, companies have played crucial roles in convincing resource-rich governments to implement the EITI standard. For example, ExxonMobil was instrumental in Equatorial Guinea's accession to the EITI (Committee, 2008). Similarly, BP was key to Azerbaijan's membership and Shell in Nigeria has actively supported the country’s EITI membership since 2002 (Aaronson, 2011).

The EITI also established partnerships with the World Bank, the International Monetary Fund, the European Bank for Reconstruction and Development and the Asian Development Bank (EITI, 2014f). This multilayered and cosmopolitan structure of the initiative allows more flexibility to work with a diverse set of countries and under different political environments. Yet, this flexible structure also undermines effective implementation of reform because the stakeholders and EITI members have diverging interests regarding the goals and the strategy of the initiative. Member governments and companies focus on bolstering global credibility, competitiveness, and profitability. On the other hand, international organizations and civil society groups focus on issues of governance and expect substantial improvements in tax collection processes and the fight against corruption (Aaronson, 2011).

How does the EITI function? The EITI uses a relatively a narrow definition of transparency that focuses only on governments' revenues. Accordingly, participating oil, gas, and mining companies are required to publish what they pay to the governments of their host countries and the governments are required to publish what they receive. An 
Author: Kerem Öge

independent firm then comparatively audits these published accounts. Subsequently, local NGOs assess these reports and offer comments and suggestions for improvements. The Multi-Stakeholder Group, composed of designated representatives from the government, companies, and civil society groups, supervises this whole process in each EITI country (Eigen, 2006). By making the revenues more transparent, the promoters of the EITI expect improvements in anti-corruption efforts and tax collection processes. The EITI process also anticipates improved trust and stability in the extractive industries, which would eventually encourage long-term investments and ensure supply security (EITI, 2014c).

The initial blueprints of the EITI included measures to have all oil, natural gas, and mineral companies disclose their payments to resource-rich governments. ${ }^{2}$ However, in the current EITI structure, the responsibility to disclose falls mostly on the member governments (Frynas, 2010). Companies that operate in EITI-implementing countries are required to "disclose all material payments in accordance with the agreed reporting templates and in line with the company's audited figures" and "cooperate to remedy any discrepancies identified by the Independent Administrator" (EITI, 2013a). In cases where companies fail to report, the host country may lose its compliant status, however, there is no formal punishment for the companies. ${ }^{3}$

Various major corporations publicly endorse the EITI process and comply with their obligations in EITI-implementing states even though they are not legally required to do as such. However, they have yet to adopt revenue transparency as a general policy

\footnotetext{
${ }^{2}$ Interview with Dr. Francisco Paris, EITI Regional Director, 10 May 2011, Oslo.

${ }^{3}$ In some EITI countries, such as Nigeria and Norway, companies are legally bound to comply with the standard (EITI, 2013a).
} 
Author: Kerem Öge

(Frynas, 2010; Ross, 2015). In fact, besides their responsibilities in EITI-members, EITI supporting companies such as Chevron, ExxonMobil, and Total rarely disclose their payments to governments. A study in 2012 found out that only 17 out of 53 EITI supporting companies reported country-payments in a consistent manner (Toledano, 2012). This outcome once again confirms that the EITI standard applies exclusively to resource-rich governments while supporting companies are only asked to disclose when the host governments comply with the initiative.

Despite the substantial influence of the EITI over the resource-rich countries, this multifaceted organization remains understudied. A small number of studies focus on the general implications of the initiative (Aaronson, 2011). Similarly, reports by international observers point out to the challenges the initiative faces and provide suggestions on how the EITI should move beyond its given mandate (Dykstra, 2011; Revenue Watch Institute, 2006). These are also several single case studies and reports that examine the challenges the initiative faces in different political and social contexts (Bagirov, 2007; Keblusek, 2010; Öge, 2014; PPRC, 2005). More recently, a number of studies have focused on EITI's impacts on corruption and good governance (Kasekende, Abuka, \& Sarr, 2016; Öge, 2016; Papyrakis, Rieger, \& Gilberthorpe, 2016; Sovacool, Walter, Van de Graaf, \& Andrews, 2016). To the best of this author's knowledge, there is only one empirical study on the causes of EITI membership; however it focuses mostly on corruption as an explanatory mechanism (David-Barrett \& Okamura, 2013). The literature on compliance so far lacks a viable explanation of why states voluntarily disclose their revenues in their strategic industries. The following section discusses the mechanisms through which countries decide to adopt revenue transparency. 
Author: Kerem Öge

\section{Why do countries join the Extractive Industries Transparency Initiative?}

In the literature on democratization, traditionally, endogenous variables take precedence as potential causes of domestic reforms (Pevehouse, 2002). Accordingly, a 'domestic push' for democratization from a grassroots movement is more likely to have an impact on the political regime in comparison to an 'international pull' (Levitsky \& Way, 2006). Yet, one can argue that international factors, such as the distribution of economic and political power (Gourevitch, 1978), or flow of ideas and norms (Finnemore, 1993; Finnemore \& Sikkink, 1998), can also shape leadership preferences on institutional reforms. The new institutionalist tradition offers two logics on how international policies can be embraced by decision-makers: the logic of consequences and the logic of appropriateness (March \& Olsen, 1984).

The logic of consequences implies that only direct material benefits from future compliance would encourage the leadership to reform institutions as demanded by international actors. According to this perspective, governments comply with the demands of transparency advocates when the costs of compliance are less than the benefits. Before making the decision to join the EITI, the political elite evaluates shortterm costs and benefits of EITI compliance, bearing in mind the strategic importance of resource revenues for their political success. I identify two mechanisms of policy diffusion, which are relevant for the calculation of these costs and benefits as a rational process: learning and competition (Graham, Shipan, \& Volden, 2013).

Learning implies that as rational decision-makers, leaders carry out policies for their observed, positive results. The primary intended goal of the EITI is to facilitate a transparent resource management process. While majority of a country's citizens might 
Author: Kerem Öge

support such an outcome, revenue transparency may not necessarily be in the best interests of politicians. The disclosure of government revenues and the subsequent monitoring process by civil society groups can threaten existing patronage networks. This type of transparency could also raise awareness and mobilize public dissent especially if the majority of the population lives in poverty. These political costs of revenue transparency can be quite substantial for many non-democracies. As a result, one should expect more corrupt governments to actually refrain from the EITI process.

A second mechanism of policy diffusion that relates to rational decision-making is competition. In an increasingly globalized world, states compete with each other to demonstrate and signal their hospitability to foreign capital (Elkins \& Simmons, 2004). The competition to attract FDI is particularly fierce due to its positive impacts on employment, technological progress and economic growth (De Soysa \& Oneal, 1999; Jensen, 2003). This type of competition is essential for resource abundant countries because extractive industries often require long-term, capital-intensive investments from multinational companies to maintain and increase production levels.

How does EITI membership relate to FDI? A now rather extensive literature links information and uncertainty to international investment (Baker, Bloom, \& Davis, 2013; Bloom, 2009; Carlsson \& Van Damme, 1993; Leblang \& Satyanath, 2006; Morris \& Shin, 1998; Rodrik, 1991). Since, the EITI process increases the amount of available information to potential foreign investors, it can have a direct, positive impact on FDI levels. Foreign investors, who are typically risk-averse, would be more likely to increase their investment levels when they have access to more information and can make longterm projections. As a result, countries that depend on investment from international 
Author: Kerem Öge

companies would be more eager to sign in to the EITI initiative to both maintain and lure FDI.

Another reason why resource-rich countries might join the EITI is to signal their commitment to economic liberalization. This would allow them to attract FDI not only in the extractive industries but in all sectors of the economy. Signaling norms for potential benefits in a competitive environment is commonplace especially when the international audience "develops the belief that all desirable types engage in a specified behavior" (Hyde, 2011). In the last decade, transparency has become such a desirable norm for resource-rich countries.

For a resource-rich country, being member to the EITI signals openness, ease of business and stability, which are all key considerations for foreign investors. In this context, EITI membership signals credibility to all investors and may legitimize the operations of multinational companies even if the host government is authoritarian and corrupt. This type of signaling is not unique to resource-rich countries. In fact, similar processes can be observed in the area of central bank independence (Johnson, forthcoming) and electoral monitoring (Hyde, 2011).

The two mechanisms of learning and competition describe rational processes. An alternative perspective on norm diffusion is offered by the logic of appropriateness. In contrast to the logic of consequences, the logic of appropriateness focuses on the internalization of norms and the development of political identities and preferences that favor institutional change. According to this logic, politicians adopt institutional reforms because they believe in their inherent virtue. The logic of appropriateness is mediated by norm entrepreneurs (Börzel \& Risse, 2003, p. 59), which mobilize and persuade other 


\section{Author: Kerem Öge}

actors to redefine their interests by using moral arguments. In resource-rich countries, transparency advocates or principled issue networks spread the norm of transparency across borders. They target both elites and the society at large in order to persuade them to reconsider their identities and goals, in a process, which can be defined as socialization (Graham et al., 2013).

The mechanisms via which these two logics often operate are often interrelated and take place simultaneously. Leaders, who are rational decision makers and utility maximizers, may also genuinely believe in the inherent virtue of reforms. Even within the same government, one can find "certain ministers of energy, who are captured by interest groups, sitting next to a minister of finance who wants to do the right thing". ${ }^{4}$ However, for the case of EITI membership, the material factors are likely to precede ideational ones due to the immense importance of extractive industries for the survival of political leadership in resource-dependent countries. This assumption underlines the importance of learning and competition, as rational processes. While many elites within government bureaucracies might eventually socialize into transparency as a global norm, the initial decision to join the EITI is more likely to be determined by calculations of immediate costs and benefits. Based on these discussions, I propose two main hypotheses. First, I expect countries to be more open to EITI membership if they have an incentive to accommodate foreign capital. Secondly, I expect countries to observe even higher levels of FDI in all sectors of the economy once they become members as a consequence of increased informational flows and signaling activity. The following section presents the model and the data.

\footnotetext{
${ }^{4}$ Interview with Dr. Francisco Paris, EITI Regional Director, 10 May 2011, Oslo.
} 


\subsection{Cross-National Analysis}

The cross-national analysis aims to discover the underlying causes of EITI membership, which is the dependent variable. The EITI is a dichotomous variable, which takes the value " 1 " if a country has made an official membership application and takes the value "0" if not. 46 EITI-implementing countries (both candidate and compliant) as of September 2014 are listed in Table 1 and they vary extensively in terms of geographical location and level of economic and political development (EITI, 2014a). To be compliant, candidate countries are expected to publish detailed, yearly reports on their extractive industries, which are closely monitored by independent auditors and civil society groups and disseminated via official government websites (EITI, 2013b). ${ }^{5}$

\section{[Table 1 here]}

The first independent variable is corruption $(C O R)$. The promoters of the EITI presume that revenue transparency will eventually lead to broadscale anti-corruption reforms. Based on this logic, one could argue that corrupt governments would rather avoid the EITI in order to prevent such reforms. However, the decision to join the EITI would actually depend on governments' perception of the initiative. As the current EITI process is only limited to revenue transparency, corrupt countries could still be interested in membership if they do not expect the initiative to have any substantial impacts on existing corruption networks. In this latter scenario, EITI membership would improve governments' international prestige and attract foreign investment with relatively limited political costs. To measure corruption, I use the Worldwide Governance Indicators data,

\footnotetext{
${ }^{5}$ Afghanistan, Chad, Sierra Leone, Timor-Leste, Equatorial Guinea, Democratic Republic of Congo, Myanmar, Tajikistan, and Liberia are EITI-implementing countries, but they could not be included in the regressions due to absence of data.
} 
Author: Kerem Öge

which is a continuous index based on surveys of experts and entrepreneurs. The index runs from -2.5 to 2.5 with higher scores associated with lower levels of corruption (World Bank, 2013).

The second independent variable is foreign direct investment $(F D I)$, and it is the main variable of interest identified by the mechanism of competition. I expect higher percentage ratios of incoming foreign direct investment in the economy to be correlated with greater likelihood of EITI membership. To measure this variable, I use foreign direct investment, net inflows (\% of GDP) from World Development Indicators (World Bank, 2014). The third independent variable in the main model is economic wealth. I expect economic wealth to correlate negatively with EITI membership since poorer countries would have more incentives to signal for material gains. To measure income, I use a $\log$ of GDP per capita (INCOME), which indicates the relative economic vulnerability of a country and its dependence on foreign investment (World Bank, 2014).

Finally, I also include four additional variables (CTR) to control for other political, economic, and regional factors. The first additional variable, Voice and Accountability $(V A)$, is an indicator for democratic participation. Democracy is known to correlate with transparency, economic openness and corruption. If democratic governments are more willing to join the EITI, then the coefficients on both the corruption and FDI terms might be biased. The VA index, which addresses this issue when used as a control variable, runs from -2.5 to 2.5 with higher scores associated with higher levels of political liberties (World Bank, 2013).

Liberalized economies may be keener to join the EITI, perhaps because they are already in compliance with certain provisions of the EITI. Hence, the second control 


\section{Author: Kerem Öge}

variable is economic liberalization (ECOFREE) and it is measured by the index of economic freedom (Heritage, 2015), which runs from 0 (least free) to 100 (most free).

The third control variable is an indicator of natural resource rents. The primary implication of transparency promotion is better management of natural resources. Therefore, I expect governments to be more eager to join the EITI if their subsoil resources make a substantial contribution to their economies. I use total natural resources rents (\% of GDP) to measure this variable (RENT) (World Bank, 2014).

Table 1 reveals that many EITI members are from Sub-Saharan Africa. Accordingly, the final additional variable one is a dummy for that region $(S U B S A H)$. A positive correlation could signal the presence of a geographical diffusion mechanism among Sub-Saharan countries in their attitudes towards the initiative.

All variables reflect scores from 2010, except for the FDI variable, which is averaged over seven years (2006-2012) to account for yearly fluctuations and missing data. Since the dependent variable takes only ' 0 's and ' 1 's as values, I use logistic regression to test the hypotheses above. Based on the variables described, the model can be specified as follows:

$$
\begin{gathered}
\mathrm{PR}(E I T I=1 / C O R, F D I, I N C O M E, C T R)=\mathrm{F}\left(\beta_{0}+\beta_{1} C O R++\beta_{2} F D I+\beta_{3} I N C O M E+\text { CTR }\right) \\
, \text { or alternatively: } \\
\operatorname{PR}(E I T I=1 \mid C O R, F D I, I N C O M E, C T R)=\frac{1}{1+\left(\frac{1}{e^{(\beta 0+\beta 1 C O R+\beta 2 ~ F D I+\beta 3 I N C O M E+C T R)}}\right)}
\end{gathered}
$$

In accordance with my hypotheses, I expect a negative sign for $\beta_{3}$, while the sign for $\beta_{1}$ will depend on whether or not corrupt governments perceive the EITI as a threat. $\beta_{2}$ will be the coefficient of main interest for the purposes of this paper. A positive sign for 
Author: Kerem Öge

$\beta_{2}$ would mean that countries that have higher share of FDI inflows in their economies are more likely to become EITI members.

\subsection{The Results}

Table 2 reveals the coefficients of the series of logistic regressions based on the model. For the first three columns, the case selection includes all countries in the world where data was available. The first column shows the results of the basic model with only three variables (corruption, FDI, and income). In Column 2, voice and accountability, economic freedom, natural resource rents are introduced as control variables. Finally the third column includes the dummy variable for Sub-Saharan countries. The last three columns repeat this exercise; however, this time the OECD countries are dropped from the analysis in order to test the effectiveness of the model without major industrialized, rich countries.

[Table 2 here]

The results confirm the main hypothesis of this paper on the significance of the competition mechanism for non-OECD countries. The FDI, which is the main variable of concern, is consistently significant when industrialized countries are dropped from the analysis and its coefficients have the expected positive signs in all variations of the model. This outcome implies that higher percentage of incoming FDI is actually associated with a higher likelihood of EITI membership.

Table 3 shows the same results with odds ratios instead of logistic regression coefficients, which is helpful in interpreting the impact of independent variables on the outcome variable. In the first column, we can see that a 1-unit increase in the FDI increases the odds of EITI membership by 1.047 . The impact of the FDI variable is much 
Author: Kerem Öge

higher when the OECD countries are dropped from the model. For example, in Column 6, a 1-unit increase in FDI increases the odds of EITI membership by 1.153. This suggests that the impact of FDI is more profound for lower and middle-income countries.

[Table 3 here]

One can understand the relationship between the two variables even better by looking at predicted probabilities of EITI membership at given FDI levels while keeping other variables at their means. ${ }^{6}$ Table 4 shows predicted probabilities of EITI for three different $F D I$ values. The mean value of $F D I$ for all countries is 6.51 percent. In the first column, a 5 percent increase from the mean of FDI raises the likelihood of EITI membership by 3.6 percent $(0.214-0.178)$. When the FDI rises 10 percent above the mean, the model predicts a 7.7 percent increase in the probability of EITI being equal to 1. As mentioned above, the interaction between the two variables is much stronger when OECD countries are removed from the model. For example, in Column 5, a 10 percent increase in the mean value of FDI corresponds to a 33.1 percent rise in the prospect of EITI membership.

\section{[Table 4 here]}

Moving on to other variables in Table 2, corruption negatively correlates with the EITI and its coefficient is statistically significant in all regressions. The results suggest that countries that suffer from corruption are more likely to be EITI members. Similarly, the coefficients of the income variable are also significant and have the expected negative signs.

Finally, the control variables are also consistently significant, except for the index of economic freedom, ECOFREE, which is not significant in any of the models. These

\footnotetext{
${ }^{6}$ These probabilities were calculated by using the margins command in STATA 12.
} 
Author: Kerem Öge

results show that EITI membership is positively correlated with political liberties and natural resource rents. Interestingly, the results also reveal that Sub-Saharan countries are more likely to become EITI members. Table 5 displays the predicted probabilities of EITI membership based on the values of $S U B S A H$. Accordingly, among non-industrialized economies, the likelihood of EITI membership increases by 27.4 percent if a country is from Sub-Saharan Africa.

[Table 5 here]

\subsection{Discussion}

Firstly, the results support the hypothesis generated by the competition mechanism, the main argument of this paper. Specifically, the analysis establishes that current EITI members have higher FDI inflow levels compared to non-member countries. Yet another question remains: do FDI levels increase even further after EITI membership?

In order to address this issue, I employ an interrupted time-series design (ITS), which displays the causal impact of an intervention by assigning a cutoff point (Biglan, Ary, \& Wagenaar, 2000; Gillings, Makuc, \& Siegel, 1981; Lewis-Beck \& Alford, 1980; Linden, 2015; Muller, 2004). This design compares the values of the dependent variable on two sides of the cutoff point in order to identify changes in the slope caused by the intervention. To measure the impact of EITI membership on FDI levels, I determine the cutoff point to be the year a country becomes an EITI member. Naturally, the actual year of membership varies for each country. To be able to test the impact of EITI membership across cases, I create a rating variable, TIME, which is a running count of integers. For each country, the variable takes the value " 1 " the year of membership and increases by 
Author: Kerem Öge

one every year. The count also goes backwards in order to demonstrate the trend in FDI levels immediately before membership. This way, the ITS analysis measures the impact of EITI membership on FDI levels. The regression equation for this ITS can be expressed as follows (Huitema \& Mckean, 2000; Linden \& Adams, 2011; Simonton, 1977):

$$
F D I_{\mathrm{t}}=\beta_{0}+\beta_{1} T I M E_{\mathrm{t}}+\beta_{2} M E M B E R_{\mathrm{t}}+\beta_{3} T I M E_{\mathrm{t}} M E M B E R_{\mathrm{t}}+\varepsilon_{\mathrm{t}}
$$

FDI is the dependent variable, which is measured again by foreign direct investment, net inflows (\% of GDP) from World Development Indicators (World Bank, 2014). TIME is a running count of integers as explained above. MEMBER is a dummy variable, which takes the value 1 if a country is an EITI member in a given year and 0 if a country is not a member yet. The model also includes an interaction of TIME and $M E M B E R$. The coefficient for $M E M B E R\left(\beta_{2}\right)$ indicates change in FDI levels immediately after the intervention. The coefficient of the interaction variable $\left(\beta_{3}\right)$ represents the difference in the slope of the outcome variable before and after the intervention, identifying longer-term dynamics. Table 6 shows the outcome of the OLS-regression based on the ITS model. The only significant variable is the interaction, which suggests that the treatment effect is not immediate but it is felt over time (Linden, 2015). The positive value of this coefficient implies that incoming FDI levels are significantly higher in the period after membership.

\section{[Table 6 here]}

The graphical presentation is perhaps the most direct way to demonstrate this outcome (Jacob, Zhu, Somers, \& Bloom, 2012). Accordingly, Figure 1 shows the relationship between the dependent variable and TIME and for all EITI members. The variable TIME permits us to visualize the relationship between FDI and EITI affiliation 
Author: Kerem Öge

as if all countries became members in the same year. The graph demonstrates that overall levels of FDI inflows are higher after membership as previously shown by the regression analysis.

[Figure 1 here]

In ITS analysis, using a control group of non-EITI members is a common method to provide additional validity to the results. However, since membership date among EITI countries is not uniform, it is not possible to set a cut-off point for the members of the control group. Alternatively, Figure 2 shows FDI levels for non-EITI resource-rich countries between 2006 and 2013, a period in which most current EITI-affiliated countries have became members. The graph actually reveals a declining trend among these countries in terms of the ratio of incoming foreign investment in the economy. This outcome confirms the lack of an exogenous intervention, which could have distorted the results of the ITS analysis. It also validates the fact that EITI-accession has a significant impact on FDI levels among resource-rich countries. In sum, the ITS analysis shows that EITI members not only have higher FDI levels compared to non-members, but these investments increase further once countries join the initiative.

[Figure 2 here]

The results re-confirm the presence of signaling and the validity of the competition mechanism. When countries seek to attract FDI for economic growth and employment, they are also expected to demonstrate their willingness to accommodate foreign capital by liberalizing their institutions. As a result, the presence of multinationals in resource-rich countries increases leadership incentives to apply for EITI membership since most of these companies are EITI stakeholders. Currently, Chevron operates in 20 
Author: Kerem Öge

EITI implementing countries, Glencore in 13, Total in 12, Shell in 10, BP in 8 and Rio Tinto in 7 (EITI, 2014f).

It is important to note that the norm of transparency impacts not only resourcerich countries but also corporations. In fact, many international companies are pressured by their home states to disclose their payments to foreign governments through measures such as the Dodd-Frank Act in the United States or the Accounting Directives in the EU (Bleischwitz, 2014; Hall, 2013). Interestingly, while companies lobby extensively against these national legislations, they are generally supportive of the EITI process. Corporations prefer the EITI's non-binding, voluntary approach to transparency as opposed to more strict national legislations, which can undermine their competitiveness. In addition, by supporting the EITI process, multinational companies present themselves as norm-promoters and aim to improve their popular image (Gillies, 2010). These reputational gains are important for high-profile companies who often come under intense scrutiny for their operations in developing countries.

It is important to note that competition for global capital may not be correlated with good governance under all circumstances. Unlike Western countries, Russia and China have strictly business-related agendas, and they are often indifferent to good governance in their supplier states (Taylor, 2006; Zweig \& Jianhai, 2005). These diverging perspectives often bring international actors at odds with each other on highprofile cases of human rights abuse. For example, OECD governments severely criticized national oil companies (NOCs) from China, India, and Malaysia during the 2000s for prioritizing their business interests despite the ongoing humanitarian crises in Burma and Sudan (Barnes \& Jaffe, 2006, p. 14). The competition of Western countries with Russia 
Author: Kerem Öge

and China over the control of limited energy resources and routes can have a direct impact on the quality of institutions in resource-rich states (Öge, 2015). In particular, countries that have closer commercial interactions with NOCs from Non-Western states will have fewer incentives to be more transparent (Chen \& Jaffe, 2007). Further research could shed more light into the relationship between different sources of FDI and transparency.

Secondly, another interesting result is the tendency among Sub-Saharan African countries to be EITI members. This outcome may signify the existence of a geographical diffusion mechanism in the region. Gold-rich Ghana and oil-rich Nigeria were the first African countries that participated in the initiative, yet they were quickly followed by Equatorial Guinea, Cameroon, Gabon, Guinea, Mauritania and Niger (EITI, 2014d). EITI Regional Director Francisco Paris highlights the importance of regional effects during the compliance process: "In a francophone African country, they [the EITI representatives] were very intrigued by the fact that Central African Republic was able to comply. They were asking why they could not comply, yet Central African Republic could."7 More in depth studies are required to substantiate the causal mechanism of geographical diffusion in Sub-Saharan Africa. A common theme among the early adopters is the presence of Western foreign companies in the extractive sector; however there is no single energy or mining company that is responsible for the outcome.

Thirdly, the results in this research show that countries, which suffer from corruption, are also more likely to be EITI members. At first glance, this outcome appears counterintuitive. In theory, at least, corrupt governments should have no

\footnotetext{
${ }^{7}$ Interview with Dr. Francisco Paris, EITI Regional Director, 10 May 2011, Oslo.
} 
incentives to join the EITI since transparency can uncover illegal and corrupt activities, which may implicate government officials. However, given the narrow definition of transparency in the EITI process, many leaders perceive the associated costs of compliance as acceptable. Eager to improve their international image and attract foreign investment, these countries are able to sign on to the EITI without necessarily changing their usual modus operandi. Thus they implement a limited form of revenue transparency, while still keeping a tight lid on how these revenues are spent (Öge, 2014, 2016). Finally, the results also reveal that low-income countries are more likely to be EITI members. Here, the main implication is that poorer countries have more incentives to signal their compliance with global standards of transparency in order to attract FDI, which is associated with higher economic growth (De Soysa \& Oneal, 1999).

How to interpret countries that do not fit the model? Table 7 displays a list of countries and their predicted probabilities of EITI membership based on the complete model. ${ }^{8}$ Accordingly, the United States, Norway, and Seychelles emerge as unexpected EITI countries. For instance, the model predicts that there is 1 percent probability for the United States to be an EITI member. Similarly, Norway's predicted probability of EITI membership is only 2 percent. As high income, well-governed countries with limited inflows of FDI, there is little expectation for the United States and Norway to be affiliated with the initiative. In that sense, they are clearly outliers. However, since both countries are important producers of hydrocarbons, their membership has a symbolic meaning. As exemplary cases of resource-led economic development, these countries make EITI membership more compelling to other developing resource-rich countries. Since Norway and the United States already have high standards of resource governance,

\footnotetext{
${ }^{8}$ These probabilities were calculated by using the predict command in STATA 12.
} 
Author: Kerem Öge

there is also no political cost of membership. Other industrialized countries such as the United Kingdom and Germany, have joined the initiative since September 2014, and Canada and Australia may follow suit in the near future to setup examples for other resource-rich states.

[Table 7 here]

The case of Seychelles is perhaps more interesting. At the moment, the scarcely populated archipelago does not produce hydrocarbons or minerals; however, international oil companies are exploring the potential of offshore petroleum reserves (EITI, 2014e). As a country highly dependent on foreign direct investment, the decision of the African nation to join the initiative underlines the argument of this paper with regards to the competition mechanism. Alternatively, a potential geographical diffusion mechanism in Sub-Saharan Africa may have also contributed to the unlikely membership of Seychelles to the EITI.

Finally, how to evaluate countries that have not joined the initiative? The EITI has been quite successful in attracting small and medium level hydrocarbon-rich countries. However, with the exception of the United States, major players in global energy markets have not shown any interest in the initiative. For example, Russia, Saudi Arabia, Iran and China, which collectively produce approximately a third of world's oil and gas output, are not EITI members (EIA, 2016). While more in-depth research is required to understand why these countries did not pursue EITI membership, the model here can offer some insights. Firstly, Russia, Saudi Arabia, Iran and China all have low levels of FDI inflows (World Bank, 2014), confirming the predictions of my main hypothesis. Furthermore, unlike the United States, these countries exercise substantial control over 
Author: Kerem Öge

their extractive industries through established state-owned enterprises. Finally, also consistent with my model, these countries have upper middle income levels with the sole exception of Iran, which has been suffering from economic sanctions until recently. These three factors reduce the appeal of the initiative for these countries that have substantial energy reserves and do not urgently require FDI. Other potential explanations for their lack of interest could be related to the common perception of the EITI as a club for poor African countries or as an agent of Western influence (Munje, 2014).

\section{Conclusion and Policy Implications}

Various forms of external influences attempt to initiate political and economic reforms in developing countries. In the last decade, international financial institutions and global advocacy networks have promoted transparency to facilitate better decisions, policies, and processes without necessarily causing a fundamental shift in the political regime. In resource-rich countries, the EITI emerged as the most effective mechanism for ensuring transparency in government revenues from hydrocarbons and minerals. The EITI is increasingly more popular; however the literature lacks an underlying mechanism of its membership patterns that can explain why states volunteer to disclose their precious revenues.

As one of the first comprehensive comparative studies on the EITI, the results in this paper show that EITI membership is correlated with lower levels of income and higher levels of resource dependency, corruption, and FDI inflows. In particular, the impact of FDI is crucial in explaining policy decisions on revenue transparency, since other variables are unlikely to fluctuate strongly in the short run. As the case of Seychelles shows, even the prospect of petroleum extraction can initiate the membership 
Author: Kerem Öge

process in the existence of high FDI inflows. Improved bilateral relations with Western states and international firms, and having access to supply chains offer additional resources to domestic actors, motivating them to signal their commitment to transparency. This process of signaling for material benefits can apply to any norm diffusion process, including promotion of human rights and environmental advocacy.

The results also imply that while industrialized countries join the initiative to setup examples for developing states, many corrupt governments apply for membership as a gesture to appease foreign investors. They signal adherence to western initiated norms without necessarily changing actual practices, a process known as mock compliance (Walter, 2008). This paper contributes to this literature, first by documenting its presence in extractive industries and second by introducing competition as an underlying mechanism.

Finally, the implications of this research raise doubts about the potential ability of the EITI as an engine of transparency reforms in resource-rich countries. The EITI does have the potential to be a wedge if elites in member states eventually internalize the norm of transparency via different mechanisms of socialization. However, the present evaluation of membership patterns highlights a rather utilitarian use of the EITI by corrupt governments. 
Author: Kerem Öge

Acknowledgements: I would like to thank Juliet Johnson for her valuable contributions to this paper. 
Author: Kerem Öge

\section{Bibliography}

Aaronson, Susan Ariel. (2011). Limited partnership: Business, government, civil society, and the public in the Extractive Industries Transparency Initiative (EITI). Public Administration and Development, 31(1), 50-63.

Bagirov, Sabit. (2007). Azerbaijani Oil: Revenues, Expenses and Risks. Baku: EITI-AZ.

Baker, Scott R, Bloom, Nicholas, \& Davis, Steven J. (2013). Measuring economic policy uncertainty. Chicago Booth research paper(13-02).

Barnes, Joe, \& Jaffe, Amy Myers. (2006). The Persian Gulf and the Geopolitics of Oil. Survival, 48(1), 143-162.

Berliner, Daniel. (2014). The political origins of transparency. The Journal of Politics, 76(02), 479-491.

Biglan, Anthony, Ary, Dennis, \& Wagenaar, Alexander C. (2000). The value of interrupted time-series experiments for community intervention research. Prevention Science, 1(1), 31-49.

Bleischwitz, Raimund. (2014). Transparency in the extractive industries: Time to ask for more. Global Environmental Politics, 14(4), 1-9.

Bloom, Nicholas. (2009). The impact of uncertainty shocks. Econometrica, 77(3), 623685.

Börzel, Tanja A., \& Risse, Thomas. (2003). Conceptualizing the Domestic Impact of Europe. In K. Featherstone \& C. M. Radaelli (Eds.), The Politics of Europeanization. New York: New York University Press.

Brunetti, Aymo, \& Weder, Beatrice. (2003). A free press is bad news for corruption. Journal of Public economics, 87(7), 1801-1824.

Carlsson, Hans, \& Van Damme, Eric. (1993). Global games and equilibrium selection. Econometrica: Journal of the Econometric Society, 989-1018.

Chen, Matthew E., \& Jaffe, Amy Myers. (2007). Energy Security: Meeting the Growing Challenge of National Oil Companies. The Whitehead Journal of Diplomacy and International Relations, Summer/Fall.

Committee, US Senate Foreign Relations. (2008). The petroleum and poverty paradox: assessing US and international community efforts to fight the resource curse: Government Printing Office.

David-Barrett, Liz, \& Okamura, Ken. (2013). The transparency paradox: why do corrupt countries join EITI. ERCAS, Working Paper No.38.

De Soysa, Indra, \& Oneal, John R. (1999). Boon or bane? Reassessing the productivity of foreign direct investment. American Sociological Review, 766-782.

Dykstra, Page. (2011). EITI 2011 : Learning from Success and Challenges. Revenue Watch Retrieved 01/12, 2016, from http://www.resourcegovernance.org/sites/default/files/EITI lessons 2011-0223.pdf

EIA. (2016). International Energy Statistics. Retrieved 04/26, 2016, from http://www.eia.gov/cfapps/ipdbproject/IEDIndex3.cfm

Eigen, Peter. (2006). Fighting corruption in a global economy: Transparency initiatives in the oil and gas industry. Houston Journal of International Law, 29(2), 327-354.

EITI. (2013a). EITI Business Guide. Retrieved 04.20, 2016, from https://eiti.org/files/business-guide-may-2013.pdf 
Author: Kerem Öge

EITI. (2013b). The EITI Standard. Retrieved 10/26, 2014, from https://eiti.org/files/English_EITI\%20STANDARD_11July_0.pdf

EITI. (2014a). Colombia to apply for EITI candidature early 2014. Retrieved 09/01, 2014, from http://eiti.org/news/colombia-apply-eiti-candidature-early-2014

EITI. (2014b). EITI Countries. Retrieved 11/3, 2014, from https://eiti.org/countries

EITI. (2014c). Frequently Asked Questions. Retrieved 11/4, 2014, from https://eiti.org/faqs\#WhatEITI

EITI. (2014d). History of EITI. Retrieved 11/5, 2014, from https://eiti.org/eiti/history

EITI. (2014e). Seychelles. Retrieved 09/11, 2014, from http://eiti.org/seychelles

EITI. (2014f). Stakeholders. Retrieved 08/17, 2014, from http://eiti.org/supporters/companies

Elkins, Z., \& Simmons, B. (2004). The globalization of liberalization: Policy diffusion in the international political economy. American Political Science Review, 98, 171190.

Finnemore, Martha. (1993). International organizations as teachers of norms: the United Nations Educational, Scientific, and Cutural Organization and science policy. International Organization, 565-597.

Finnemore, Martha, \& Sikkink, Kathryn. (1998). International norm dynamics and political change. International Organization, 52(04), 887-917.

Fox, Jonathan. (2007). The uncertain relationship between transparency and accountability. Development in Practice, 17(4-5), 663-671.

Frynas, Jędrzej George. (2010). Corporate social responsibility and societal governance: Lessons from transparency in the oil and gas sector. Journal of business ethics, 93(2), 163-179.

Gillies, A. (2010). Reputational concerns and the emergence of oil sector transparency as an international norm. International Studies Quarterly, 54(1), 103-126.

Gillings, DENNIS, Makuc, Diane, \& Siegel, Earl. (1981). Analysis of interrupted time series mortality trends: an example to evaluate regionalized perinatal care. American Journal of Public Health, 71(1), 38-46.

Gourevitch, Peter. (1978). The second image reversed: the international sources of domestic politics. International Organization, 32(4), 881-912.

Graham, Erin R., Shipan, Charles R., \& Volden, Craig. (2013). The diffusion of policy diffusion research in political science. British Journal of Political Science, 43(03), 673-701.

Hall, Marc. (2013, 10 April ). EU seals deal to boost transparency of oil, gas and logging firms The Guardian Retrieved from http://www.theguardian.com/globaldevelopment/2013/apr/10/eu-transparency-oil-gas-minerals-logging

Heritage. (2015). Index of Economic Freedom. Retrieved 08/18, 2015, from http://www.heritage.org/index/

Hollyer, James R, Rosendorff, B Peter, \& Vreeland, James Raymond. (2011). Democracy and transparency. The Journal of Politics, 73(04), 1191-1205.

Huitema, Bradley E, \& Mckean, Joseph W. (2000). Design specification issues in timeseries intervention models. Educational and Psychological Measurement, 60(1), $38-58$.

Hyde, Susan D. (2011). Catch us if you can: Election monitoring and international norm diffusion. American Journal of Political Science, 55(2), 356-369. 
Author: Kerem Öge

IMF. (2007). Guide on Resource Revenue Transparency. Retrieved 03/20, 2015, from https://http://www.imf.org/external/np/pp/2007/eng/101907g.pdf

Islam, Roumeen. (2006). Does more transparency go along with better governance? Economics \& Politics, 18(2), 121-167.

Jacob, Robin Tepper, Zhu, Pei, Somers, Marie-Andrée, \& Bloom, Howard S. (2012). A practical guide to regression discontinuity. New York: MDRC.

Jensen, Nathan M. (2003). Democratic governance and multinational corporations: Political regimes and inflows of foreign direct investment. International Organization, 57(03), 587-616.

Johnson, Juliet (forthcoming). Priests of Prosperity: The Transnational Central Banking Community and Post-Communist Transformation: Cornell University Press.

Kasekende, Elizabeth, Abuka, Charles, \& Sarr, Mare. (2016). Extractive industries and corruption: Investigating the effectiveness of EITI as a scrutiny mechanism. Resources Policy, 48, 117-128.

Keblusek, Mary Ella. (2010). Is EITI really helping improve global good governance?

Kolstad, Ivar, \& Wiig, Arne. (2009). Is transparency the key to reducing corruption in resource-rich countries? World Development, 37(3), 521-532.

Leblang, David, \& Satyanath, Shanker. (2006). Institutions, expectations, and currency crises. International Organization, 60(01), 245-262.

Levitsky, Steven, \& Way, Lucan A. (2006). Linkage versus Leverage. Rethinking the International dimension of Regime Change. Comparative Politics, 38(4), 379400.

Lewis-Beck, Michael S, \& Alford, John R. (1980). Can government regulate safety? The coal mine example. American Political Science Review, 74(03), 745-756.

Linden, Ariel. (2015). Conducting interrupted time-series analysis for single-and multiple-group comparisons. Stata Journal, 15(2), 480-500.

Linden, Ariel, \& Adams, John L. (2011). Applying a propensity score - based weighting model to interrupted time series data: improving causal inference in programme evaluation. Journal of evaluation in clinical practice, 17(6), 1231-1238.

Lorentzen, Peter. (2014). China's Strategic Censorship. American Journal of Political Science, 58(2), 402-414.

March, James G., \& Olsen, Johan P. (1984). The New Institutionalism: Organizational Factors in Political Life. American Political Science Review, 78, 734-749.

Morris, Stephen, \& Shin, Hyun Song. (1998). Unique equilibrium in a model of selffulfilling currency attacks. American Economic Review, 587-597.

Muller, Andreas. (2004). Florida's motorcycle helmet law repeal and fatality rates. American Journal of Public Health, 94(4), 556-558.

Munje, Divine. (2014). The BRICS countries should open their extractives. Retrieved 04/26, 2016, from https://eiti.org/blog/brics-countries-should-open-theirextractives

Öge, Kerem. (2014). The Limits of Transparency Promotion in Azerbaijan: External Remedies to 'Reverse the Curse'. Europe-Asia Studies, 66(9), 1482-1500.

Öge, Kerem. (2015). Geopolitics and revenue transparency in Turkmenistan and Azerbaijan. Eurasian Geography and Economics, 56(1), 89-110.

Öge, Kerem. (2016). Which transparency matters? Compliance with anti-corruption efforts in extractive industries. Resources Policy, 49, 41-50. 
Author: Kerem Öge

Papyrakis, Elissaios, Rieger, Matthias, \& Gilberthorpe, Emma. (2016). Corruption and the extractive industries transparency initiative. The Journal of Development Studies, 1-15.

Pevehouse, Jon C. (2002). Democracy from the Outside-In? International Organizations and Democratization. International Organization, 56(03), 515-549.

PPRC. (2005). Implementation of Extractive Industries Transparency Initiative in Kazakhstan: problems and prospects: Public Policy Research Center.

Revenue Watch. (2013). Resource Governance Index. Retrieved 12/02, 2013, from http://www.revenuewatch.org/rgi

Revenue Watch Institute. (2006). Eye on EITI: Civil Society Perspectives and Recommendations on the Extractive Industries Transparency Initiative. London: Publish What You Pay/Revenue Watch Institute.

Rodrik, Dani. (1991). Policy uncertainty and private investment in developing countries. Journal of Development Economics, 36(2), 229-242.

Ross, Alice. (2015, 22 - July - 2015). Dodd-Frank's bid to clean up extractive industries stymied by oil business, The Guardian. Retrieved from http://www.theguardian.com/global-development/2015/jul/22/dodd-frank-actsection-1504-natural-resources-extractive-industries-oil-api-sec

Simonton, Dean K. (1977). Cross-sectional time-series experiments: Some suggested statistical analyses. Psychological Bulletin, 84(3), 489.

Sovacool, Benjamin K, Walter, Götz, Van de Graaf, Thijs, \& Andrews, Nathan. (2016). Energy Governance, Transnational Rules, and the Resource Curse: Exploring the Effectiveness of the Extractive Industries Transparency Initiative (EITI). World Development, 83, 179-192.

Taylor, Ian. (2006). China's oil diplomacy in Africa. International Affairs, 82(5), 937959.

Toledano, Perrine. (2012). The Business Case For Transparency.

Walter, Andrew. (2008). Governing finance: East Asia's adoption of international standards. Ithaca: Cornell University Press.

World Bank. (2013). Worldwide Governance Indicators. Retrieved 08/28, 2014, from http://info.worldbank.org/governance/wgi/index.aspx - home

World Bank. (2014). World Development Indicators. Retrieved 08/28, 2014, from http://wdi.worldbank.org

Zweig, David, \& Jianhai, Bi. (2005). China's global hunt for energy. Foreign Affairs, 84(5), 25-38. 